\title{
EL ARTE DE LA AMÉRICA VIRREINAL COMO COMPLEMENTO Y SUPERACIÓN DE LA FUERZA Y EL DERECHO*
}

\author{
ART IN COLONIAL AMERICA AS IMPROVEMENT \\ OF STRENGTH AND LAW
}

\section{JOAQUÍN GARCÍA-HUIDOBRO**}

\section{RESUMEN}

La indudable violencia de la Conquista fue seguida por el empeño de instaurar un nuevo orden en las tierras ocupadas. Para tales efectos, la Corona empleó el derecho, que en el caso de las Indias tuvo un carácter muy original, pues aplicó estatutos diferentes a los distintos grupos humanos. Sin embargo, el derecho no fue un instrumento suficiente para crear un espacio de encuentro donde los indígenas pudieran reconocerse a sí mismos en una medida significativa. En este trabajo se muestra cómo el arte sí desempeñó ese papel de manera más eficaz. En efecto, el llamado arte colonial no se limitó a ser una mera copia de los modelos europeos sino que presentó características muy propias, que en buena medida responden al peculiar modo de ser de los pueblos conquistados.

Palabras clave: Derecho Indiano, arte virreinal, barroco americano, barroco popular, barroco andino.

\section{ABSTRACT}

The undoubted violence of the Conquest was followed by the determination to establish a new order in the occupied lands. For these purposes, the Crown used law, which in the case of the Indies had a very original character, because it applied different statutes to different human groups. However, law was not a sufficient instrument to create

* Este trabajo forma parte de un proyecto más amplio, patrocinado por Fondecyt (n. 1150561). El autor agradece el inestimable apoyo del Max-Planck-Institut für europäische Rechtsgeschichte y del Grupo de Investigación en Filosofía Práctica de su Universidad, como también las fotografías de Daniel Concha Blanlot.

** Doctor en Filosofía y en Derecho. Profesor de Filosofía Práctica en la Universidad de los Andes. Santiago, Chile. Correo electrónico: jgh@uandes.cl 
a meeting place where indigenous people could recognise themselves in a meaningful way. This paper shows how art played that role more effectively. In fact, the so-called colonial art was not limited to being a mere copy of European models, but presented its own characteristics, which largely respond to the peculiar way of being of the conquered peoples.

Keywords: Indian law, Vice royal art, American baroque, popular baroque, Andean baroque.

Recibido: 06.12.17. Aceptado: 27.02.18.

$\mathrm{E}$ L VIOLENTO ENCUENTRO entre el Viejo y el Nuevo Mundo creó un desorden notable, pues vino a trastocar radicalmente las formas de vida de indios y peninsulares. Pero en la medida en que la presencia española en América pretendía hacerse permanente, era necesario remediar ese desorden, pues de lo contrario la conquista no podría ser seguida por un asentamiento estable. El instrumento destinado por antonomasia a instaurar un orden es el derecho. Así, en América surgió el llamado Derecho Indiano, cuyo carácter casuista y plural le permitió incluir fuentes muy diversas, que van desde la legislación y prácticas consuetudinarias castellanas a las leyes y costumbres propias de América, incluidas las de los indios, que mantuvieron su valor mientras no se opusieran a la fe católica y el derecho natural ${ }^{1}$. Además, a diferencia del sistema actual, donde todos los habitantes de un Estado están sometidos al mismo régimen jurídico, en ese entonces los diversos grupos humanos se hallaban sujetos a estatutos diferentes, como sucedía en la Edad Media².

Aunque el derecho tuvo un importante papel humanizador, se trata de un medio muy limitado, que requiere ser suplementado por otros. En el caso de América, ese complemento estuvo dado por el arte, que permitió establecer un espacio común y ciertos códigos de comunicación más o menos compartidos entre conquistadores y conquistados. En las páginas que siguen se mostrará el carácter novedoso del arte que se desarrolló en las Indias (1) y cómo la arquitectura (2), la pintura (3) y el teatro y la música

${ }^{1}$ Cf. Leyes Nuevas (1542), cap. 20; Recopilación de Indias (1680) 2, 1, 4.

${ }^{2}$ Como señala Octavio Paz, "las comunidades indígenas estaban regidas por las leyes de Indias y había estatutos especiales para los diferentes grupos étnicos: negros, mulatos, mestizos, criollos y españoles. Leyes particulares regían a las órdenes religiosas y a la Iglesia secular; otras, a los encomenderos, los comerciantes, los mineros, los artesanos, las congregaciones, las cofradías. De ahí que, con razón, el historiador Richard M. Morse defina a Nueva España como una sociedad pluralista, regida por un sistema de jurisdicciones especiales para cada grupo, acentuadamente jerárquica y paternalista" ( $\mathrm{Paz}, 1983$, pp. 33-34). 
(4) ayudaron a constituir un nuevo de espacio de encuentro entre los indios y los conquistadores (5).

\section{EL SURGIMIENTO DE UN ARTE NUEVO}

El derecho y la política suponen la mediación de la palabra hablada. En esa medida, su implantación en América se prestaba para innumerables dificultades debido a las diferencias culturales existentes entre indios y españoles, y a los consiguientes conflictos de traducción entre mundos que eran muchas veces inconmensurables. En cambio, el arte constituyó una vía mucho más inmediata de comunicación entre esos universos culturales. Dicho con otras palabras, más que resolver todas y cada una de las tensiones y malentendidos que produjo la conquista, la tarea que más contribuyó al entendimiento tuvo lugar en la creación de un nuevo espacio de encuentro, un arte propio de América. Más que con la verdad o la justicia, este espacio se vincula con la belleza. El derecho efectivamente mueve, pero por imposición, particularmente cuando es visto como la obra de una potencia conquistadora. El arte, en cambio, mueve por atracción. Uno obliga, el otro invita y, en ese sentido, tiene un estatuto superior.

Tras el arribo de los conquistadores la pintura adquirió un relieve muy particular. Ciertamente esta manifestación artística ya era conocida por los pueblos indígenas, como puede verse en determinados murales o en las ilustraciones de los códices, pero con la llegada del arte europeo adquirió otras proporciones.

El nuevo arte que surgió en América estuvo muchas veces inspirado en modelos europeos, pero experimentó transformaciones muy significativas. Uno puede confundir, por ejemplo, una pintura española y una italiana del siglo XVII, pero sería muy difícil no identificar al instante como americano un cuadro que ha sido pintado en el Cusco o Quito. Esta forma de expresión artística, que normalmente estaba ligada a temas religiosos, fue cultivada de inmediato por artistas indígenas, que constituyeron sus propias escuelas, donde mostraron gran habilidad ${ }^{3}$. Pero como su sensibilidad era distinta a la propia de los españoles, experimentaron cierta incomodidad ante los rígidos moldes que les imponía la pintura académica europea y muy pronto mostraron el deseo de no seguir de cerca esos cánones.

\footnotetext{
3 "Los testimonios de los cronistas como fray Jerónimo de Mendieta o fray Jodocko Ricke, son coincidentes al señalar la habilidad del indígena para asimilar la enseñanza artesanal y artística del español" (Gutiérrez, 1995, p. 14).
} 
El punto decisivo del distanciamiento entre los artistas del Viejo y el Nuevo Mundo estuvo dado por la pugna y ruptura de los gremios de pintores indígenas y españoles (es decir, peninsulares y criollos) en el Perú, en 1688 (De Mesa y Gisbert, 1982, p. 226)4. A partir de allí, los indios se sintieron liberados de la sujeción a ciertas técnicas europeas que para ellos resultaban forzadas, por ejemplo, la perspectiva, o el uso de la sombra para marcar las distancias, o el relieve, que les parecía eran unos recursos artificiales. Es decir, a los indios les interesaba representar a Jesús, la Virgen o los santos a su manera, de acuerdo con su sensibilidad. Su dificultad no estaba dada por los temas de la iconografía cristiana: de hecho, siguieron inspirándose en grabados europeos (De Mesa y Gisbert, 1982, p. 138), sino con una forma de interpretarlos que implicaba el recurso a herramientas racionales $o$ académicas, que no encajaban con su modo de ver la realidad. Si se piensa en las técnicas pictóricas del Renacimiento y el Barroco europeos, se advertirá que su énfasis está puesto en la percepción del espectador. Este quiere ser "engañado" mediante esos recursos artísticos, con el fin de tener una experiencia que se aproxime todo lo que sea posible a la realidad. A los indios, por el contrario, eso no les interesa en absoluto. De ahí, por ejemplo, su desinterés por las proporciones: si el cuadro gira alrededor de un santo o la Virgen, sus figuras aparecerán mucho más grandes que aquellas que representan a otros personajes, porque lo importante no es la impresión de realidad sino el mensaje que se quiere transmitir.

También resulta interesante destacar el modo diferente en que indígenas y españolas se relacionan con el oro. Para los primeros, la codicia que mostraban los españoles para con ese metal resultaba sencillamente inexplicable. Ciertamente ellos lo conocían, pero su uso estaba destinado fundamentalmente al culto, de modo que su empleo estaba limitado por su función. En la mentalidad europea, en cambio, el oro era visto como un medio de cambio, lo que significaba que era posible, e incluso conveniente, acumularlo sin medida alguna. En el profuso empleo del oro en la pintura y otras manifestaciones artísticas realizadas por indígenas, se observa una suerte de empeño por devolver a ese metal el uso religioso de que estaba dotado originalmente (Mujica Pinilla, 2016, p. 218) (Fig. 1).

\footnotetext{
${ }^{4}$ Una discusión de esta tesis en Valenzuela (2013).
} 


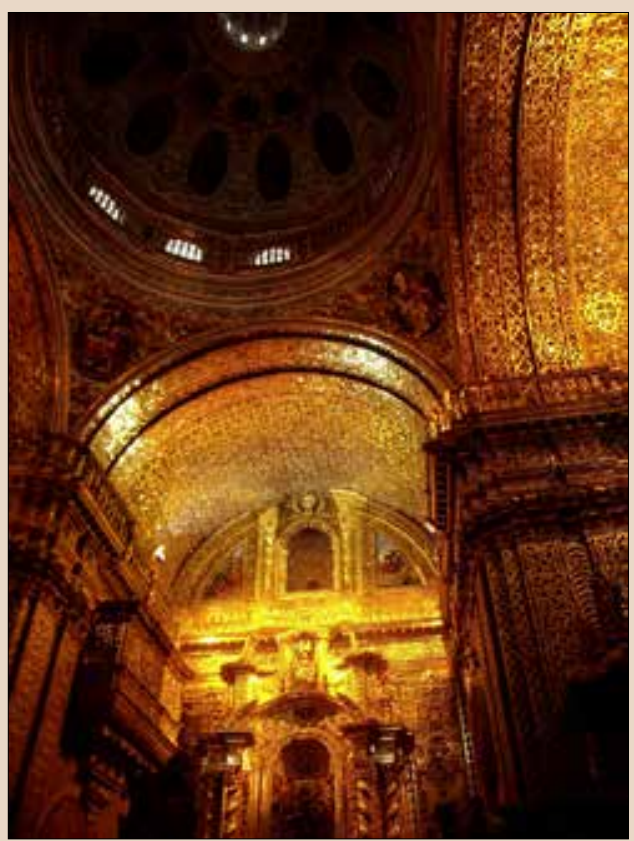

Figura 1. Iglesia de la Compañía de Jesús.

A partir de 1688, los artistas indios comenzaron a realizar sin trabas un arte que a nosotros nos parece un tanto ingenuo, pero que corresponde mucho mejor a la sensibilidad religiosa de los indígenas y el resto del pueblo menos letrado, para cuya devoción se realizaban las distintas obras de arte en las iglesias. El hecho de que los indios reivindicaran con fuerza su propio modo de representar plásticamente la fe cristiana parece una señal clara de que, por entonces, ya no la consideraban un cuerpo extraño en sus vidas, sino que el arte les había proporcionado un camino para acercarse a esa fe de un modo ajustado a su sensibilidad 5 .

La diferencia entre los europeos y ellos no obedecía a la menor capacidad técnica de estos últimos, sino a la distinta mentalidad de unos y otros, que los lleva a preferir diferentes lenguajes para expresar la realidad. Así, Melchor Pérez de Holguín y Luis Niño son contemporáneos, pero sus estilos difieren completamente porque el primero pinta como un europeo,

\footnotetext{
${ }^{5}$ En sentido contrario, Estenssoro (2003).
} 
mientras el arte del segundo es propio del Nuevo Mundo. Pero en ambos casos esta autoexpresión implica cierta novedad respecto del pasado, porque no se realiza con las modalidades que eran propias del mundo de sus ancestros precolombinos (murales, vasijas o textiles), sino utilizando en la mayoría de los casos soportes y categorías que han recibido de Europa. Pero como sus obras son muy distintas a sus antecedentes, tanto europeos como indígenas, resulta claro que ha nacido un nuevo modo de expresión, un lenguaje pictórico que incluye de modo muy natural la herencia cultural que trajeron los conquistadores pero que se ha enriquecido con elementos nuevos (De Mesa y Gisbert, 1982, p. 146). En lo que sigue se mostrará en qué consiste la singularidad de este nuevo arte en las distintas formas de expresión artística.

\section{UNA ARQUITECTURA INTEGRADORA}

Dos desafíos enfrentaron los misioneros de la zona andina a la hora de desarrollar una arquitectura religiosa, uno de carácter teológico y otro práctico-pastoral.

El primero tiene que ver con la relación de los conquistadores con las prácticas religiosas de los indígenas. Ella fue ambigua y presentó modalidades muy diversas. A los recién llegados les llamó negativamente la atención la idolatría de los pueblos precolombinos y, particularmente, algunas prácticas como los sacrificios humanos y el canibalismo. De ahí que en un primer momento tendieran a pensar que el culto que celebraban los indios estaba dirigido a los demonios, y procedieran en consecuencia. El resultado de esta actitud fue el proceso de extirpación de idolatría a lo largo de todo el siglo XVI, en el marco del cual se destruyeron numerosos lugares y objetos sagrados (Arriaga, 1999).

Con todo, la relación con las religiones precolombinas fue mucho más compleja que esa actitud meramente destructiva. Así, un problema teológico que se presentó a los misioneros a la hora de definir la apariencia de los templos fue particularmente interesante: ¿correspondía incluir motivos propios de la religiosidad precolombina en los templos cristianos? ¿Cabía poner, por ejemplo, al sol o la luna (objeto de adoración por los indios), o a ciertos animales como el puma o el mono, a quienes se les atribuían caracteres divinos? En el siglo XVI hubo una fuerte polémica al respecto, entre los dominicos, que se negaban porque consideraban que era una 
concesión inaceptable al paganismo, y los agustinos (y luego los jesuitas), que eran partidarios de proceder de esa manera (Gisbert, 1994, p. 16). Finalmente primó la segunda opinión, y ya en el siglo XVII la inclusión de la iconografía pagana en los templos cristianos era una práctica común en Hispanoamérica. Para la postura que abogaba por la acogida era muy importante incluir esos elementos. Así se podrían integrar a una cosmovisión cristiana esos seres que eran objeto de idolatría. De este modo se mostraría su importancia, pero al mismo tiempo quedaría claro su carácter de creaturas del único Dios verdadero, cuya imagen ocupaba el lugar central en los templos. Vemos que aquí no se busca cortar de raíz la aspiración que está detrás de la mentalidad politeísta, sino que se la encauza y se le asigna un sentido dentro de un esquema cristiano. Por esta vía el arte hizo posible una integración que no podían conseguir las armas. De ahora en adelante, los indios podían reconocerse en las imágenes cristianas, reordenar su mundo y encontrar en él un lugar para ellos. El arte fue el medio en que se creó una nueva unidad. Como señala Octavio Paz:

Frente a la pluralidad de naciones y lenguas que componían al mundo prehispánico, Nueva España se presenta como una construcción unitaria: todos los pueblos y todos los hombres tenían cabida en ese orden universal. En los villancicos de Sor Juana [Inés de la Cruz] una abigarrada multitud confiesa en náhuatl, latín y español una sola fe y una sola lealtad. El catolicismo colonial era tan universal como la monarquía, y en su cielo, apenas disfrazados, cabían todos los viejos dioses y las antiguas mitologías (Paz, 1974, pp. 37-38).

El segundo desafío que enfrentaron los misioneros consistió en que, en muchos lugares, los indios no realizaban sus actividades de culto al interior de los templos, sino al aire libre. En cambio, para los católicos, el principal acto de culto, la misa, se realiza sobre un altar que está en un templo especialmente construido para tales efectos. Las soluciones elegidas fueron particularmente ingeniosas y se entienden en el marco del Concilio de Trento, que, tal vez por marcar las diferencias con el protestantismo, no le atribuyó una especial importancia a la participación activa de los fieles en la misa.

Así las cosas, se buscaron fórmulas que permitieran que los indios asistieran a la misa dominical sin tener necesariamente que ingresar al edificio mismo del templo. En algunas iglesias de Perú y Bolivia puede verse cómo, encima de la puerta de entrada, hay una suerte de balcón, que permite al sacerdote realizar la prédica desde allí, para catequizar a los indios que están 
en la explanada frente al templo (Fig. 2). También en muchos casos se instalaron frente a las iglesias unas capillas posas (llamadas así porque en cada una se aposentaba un santo). Ellas consisten en cuatro edificios cuadrangulares ubicados en los extremos del atrio al exterior de los templos (Fig. 3), donde se realizaban actividades litúrgicas de las que podían participar los indios sin necesidad de entrar al templo. Estas capillas, muy frecuentes en Nueva España, también se encuentran en Perú y Bolivia (Gisbert y De Mesa, 1974, pp. 973-1003). Ellas permitían fomentar la devoción a los santos, que fue un elemento que ayudó a encauzar la mentalidad politeísta de los indios hacia una estructura monoteísta cristiana ${ }^{6}$.

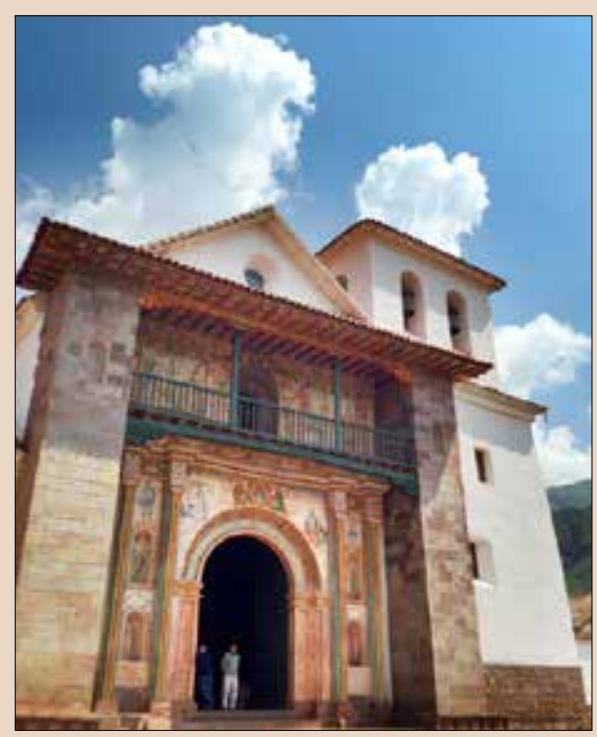

Figura 2. Fachada Andahuaylillas. Fuente: https://es.wikipedia.org.

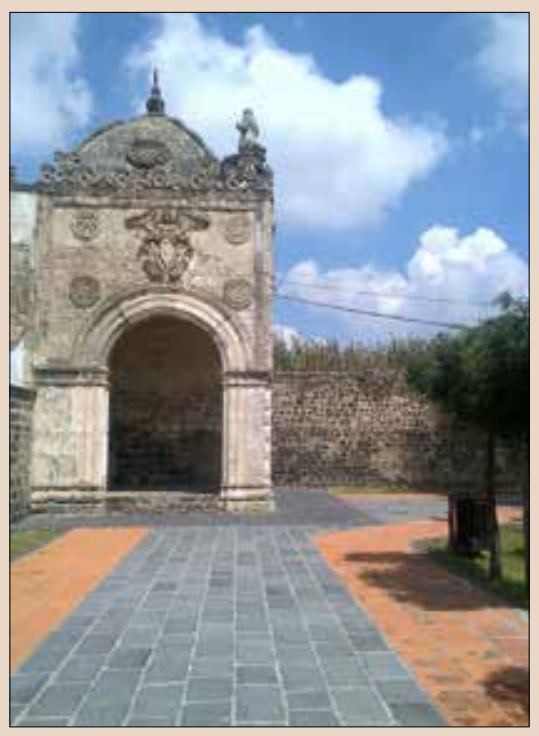

Figura 3. Capilla Posa a San Francisco Calpan. Fuente: https://es.wikipedia.org.

Dentro de las diversas vertientes que conoce el cristianismo, no cabe duda de que el catolicismo es la que está más cerca de la sensibilidad pagana: en el catolicismo la religión es algo que se ve, se toca e incluso se huele (como en el caso del incienso). Aquí nuevamente el Concilio de Trento jugó

\footnotetext{
${ }^{6}$ En la misma línea hay que incluir las fachadas-retablo barrocas (Cabello Pérez, 1989).
} 
un papel muy relevante, al reforzar el uso de las imágenes en la catequesis, como un modo de destacar la importancia de la Encarnación y de alejar a los fieles del espiritualismo protestante ${ }^{7}$. Por eso las representaciones americanas de Cristo son particularmente realistas, y muy diferentes, por ejemplo, de las que cabe encontrar en una iglesia europea medieval (Fig. 4). Los indios, como los demás americanos de entonces, organizaron buena parte de su vida alrededor de cofradías religiosas vinculadas a un santo. De esta manera, la religión se volvía algo tangible, diario, porque se vinculaba con lo más cercano. Los santos no eran objeto de adoración, que solo está reservada a la divinidad, pero sí de una especial veneración ${ }^{8}$. Ellos proporcionan a los creyentes una especial cercanía con el mundo religioso. Hay santos para todos los gustos y sensibilidades. Algunos se vinculan a determinadas necesidades, otros a un oficio, como en el caso de los patrones de las cofradías asociadas a un gremio.

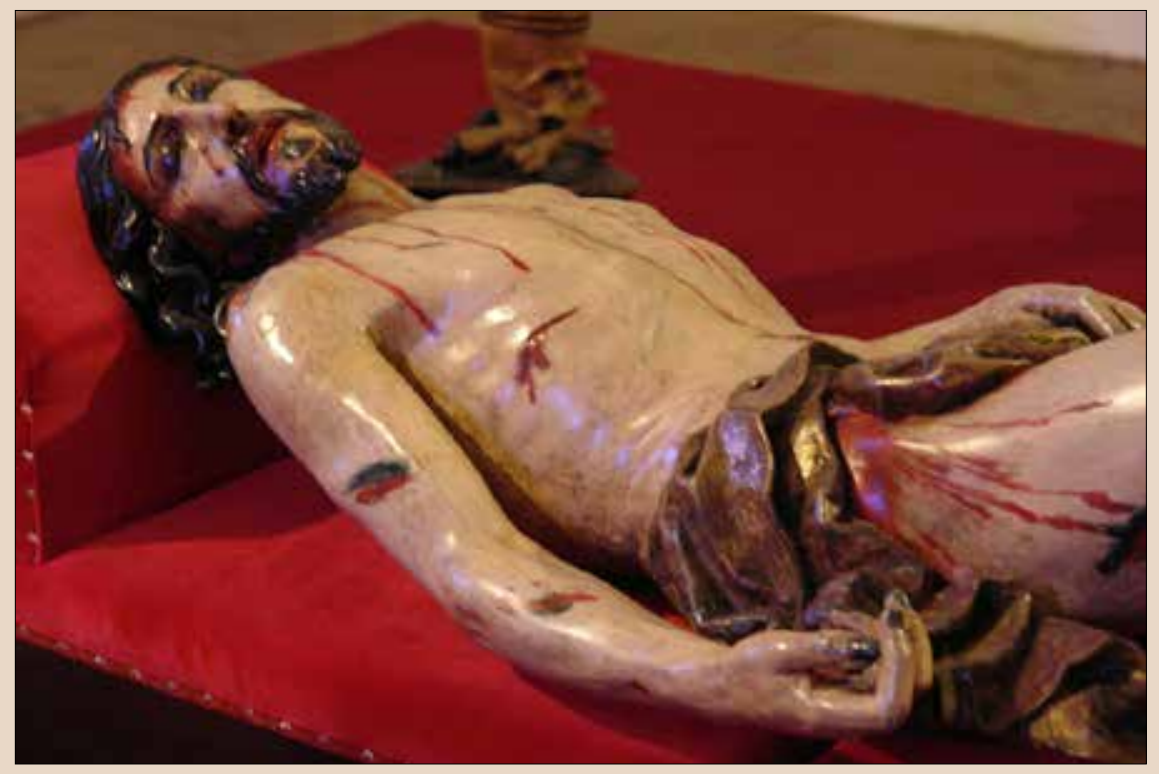

Figura 4. San Francisco-Cristo. Fuente: https://es.wikipedia.org.

${ }^{7}$ Cf. Concilio de Trento, Sesión XXV (3 y 4 de diciembre de 1563), Dz. 984.

${ }^{8}$ Cf. Concilio de Trento, Sesión XXV (3 y 4 de diciembre de 1563), Dz. 986. 
En el Altiplano boliviano podemos encontrar ejemplos muy interesantes que muestran cómo el arte, en este caso la arquitectura, dio origen a un espacio de encuentro. Se trata de diversas iglesias que han sido donadas por un cacique, como, por ejemplo, el templo de Tiwanaku, concluido en 1612. Como nadie invierte una parte considerable de su fortuna si no está realmente convencido del valor que tiene el destino de su donación, casos como este muestran que ya a comienzos del siglo XVII las figuras principales de la nobleza habían asimilado completamente la nueva fe, expresada plásticamente en esa construcción.

Lo dicho no impide, al revés, que este templo y otros semejantes sean una muestra de la incorporación de elementos de la mitología precolombina a la arquitectura cristiana. Así, en la parte inferior de las columnas que flanquean el pórtico de entrada, nos encontramos con las figuras de unos monos, pues en la mitología del lugar el mono era el dios que sustentaba los edificios 9 . El carácter religioso pagano de todos estos símbolos era tan evidente, que no cabe pensar que se trataba simplemente de formas ocultas de resistencia, como suele decirse, donde los indios habrían conseguido engañar a unos cándidos misioneros, sino más bien de un programa de inculturación perfectamente diseñado y compartido por ambas partes, los misioneros y el cacique donante, para facilitar a los indios el acceso a la fe (como se ve, por lo demás, por la discusión teológica que había tenido lugar a este respecto durante el siglo anterior acerca de la licitud de este proceder, que muestra que el tema no podía pasar inadvertido a los misioneros) ${ }^{10}$.

Con toda naturalidad, estos caciques mandaron poner al sol, la luna, el puma o el mono, todos ellos divinidades precolombinas, en la ornamentación de las iglesias cristianas. Por eso, de ahora en adelante, los indios podían reconocerse fácilmente en los templos cristianos y ver cómo sus creencias, en definitiva, apuntaban al Dios desconocido, a quien ellos habían adorado como a tientas (cf. Hech. 17, 22-23) ${ }^{11}$.

El carácter sacrificial de la misa y la devoción a Cristo crucificado, destacados muy especialmente por el Concilio de Trento, desempeñaron un papel muy importante para terminar rápidamente con la ancestral práctica de los sacrificios humanos, vigente en diversos pueblos de América. Para

\footnotetext{
${ }^{9}$ Debo esta observación a Teresa Gisbert.

${ }^{10}$ En todo caso, al colaborar en estos experimentos teológicos audaces los caciques no corrían mayores riesgos, pues los indios estaban excluidos del poder de la Inquisición (Domínguez Reboiras, 2011, pp. 60-61).

${ }^{11}$ También se pusieron santuarios cristianos en lugares que eran especialmente significativos para los aborígenes, como sucede hasta el día de hoy con el Señor de Coylloriti, en las faldas del nevado Ausangate, en la sierra peruana.
} 
acabar con otros usos los conquistadores recurrieron, como ya se dijo, a la extirpación de idolatrías, con métodos que hoy nos horrorizan, pero con los sacrificios humanos fue distinto. Ellos no desaparecieron por la acción de fuerzas externas: simplemente perdieron todo su sentido, porque el Dios cristiano no exigía la muerte de algunos hombres para que se mantenga el orden del cosmos, sino que Él mismo se había hecho hombre y se había ofrecido en sacrificio hasta la muerte. Nuevamente vemos cómo una creencia precolombina resulta no del todo suprimida sino sublimada en el conjunto del misterio cristiano. De este modo se despejaba uno de los motivos que hacían más difícil cualquier integración cultural, atendido el rechazo que los sacrificios humanos causaban en los españoles.

Muchas veces es el pueblo mismo el que adquiere protagonismo en la creación artística. En la región de Puebla abundan los templos construidos por comunidades indígenas que querían tener una iglesia, pero carecían de los medios para pagar a un arquitecto. Las realizaban valiéndose de artesanos que tenían alguna experiencia en construcciones, pero carecía de la capacidad para diseñarlas y construirlas según los cánones académicos (Terán Bonilla, 2017, p. 57). El resultado es de gran belleza, aunque los tamaños de las ventanas no siempre coinciden y estén llenas de defectos más o menos grandes (Terán Bonilla, 1992, p. 16). Estas iglesias nos muestran al menos dos cosas importantes: la primera es que el Barroco, que es el estilo que inspira a esas construcciones, fue un movimiento que tuvo una vertiente popular muy relevante. De hecho, se mantuvo en las comunidades indígenas hasta mucho después que las élites eclesiásticas y civiles habían adoptado el neoclásico y comenzado su obra de destrucción del pasado barroco, y pervivió a lo largo del siglo XIX, más allá de los procesos de independencia de sus respectivos países. Además, esas iniciativas son otra muestra de cómo el cristianismo se difundió relativamente pronto y caló muy hondo entre los indígenas. La importancia política de esta aceptación del cristianismo en un mundo donde la fe religiosa constituye un pilar de cohesión del orden social resulta fácil de entender.

\section{LA PINTURA COMO FORJADORA DE IDENTIDAD}

La cultura virreinal no tuvo un carácter primordialmente letrado, sino que se fundó en el predominio de la imagen. De ahí la importancia que revistió la pintura, que en un primer momento fue transmitida por maestros europeos, pero luego adquirió vida propia. A diferencia de la pintura europea 
del Renacimiento y el Barroco, la americana apenas se ocupó de temas seculares, como no fueran retratos. Su objeto fue casi siempre religioso, pues se la entendió como un apoyo a la devoción de los fieles y una herramienta de catequesis, como también había sucedido siglos atrás en las iglesias medievales del Viejo Mundo. En efecto, cuando se examinan las pinturas de la Catedral del Cusco o de San Pedro de Andahuaylillas, se puede constatar de inmediato que obedecen a todo un programa pedagógico destinado a introducir en la fe cristiana a los nuevos creyentes mediante imágenes $(\mathrm{Mu}-$ jica Pinilla, 2016, p. 209), atendido su carácter iletrado.

La pintura no constituyó solo un medio para transmitir la fe, sino que, como en el caso de la arquitectura, también integró a ella elementos tomados de la religión y cultura precedentes. Ella sirvió de puente entre los dos mundos y muchas veces contribuyó a forjar o consolidar el nuevo orden que se estaba fraguando en América. Un caso significativo está dado por las representaciones de María, donde su cuerpo tiene la forma de una montaña (la de Potosí) cubierta por un manto, y en la cúspide está su cabeza (Fig. 5). Como los indios daban culto a los cerros, esa era una vía que permitía integrar sus tendencias religiosas en el marco más amplio de la fe cristiana. Al mismo tiempo, las pinturas incorporaron elementos de la vida diaria andina en las representaciones de los misterios de la fe cristiana. Un caso típico es el de la Última Cena que se encuentra en la Capilla de las Madres de San Diego, en Quito, donde el cordero pascual que está en un plato frente a Jesús ha sido sustituido por un cuy, el roedor que integra la típica dieta andina, mientras que el apóstol que figura a su izquierda está comiendo unas humitas ${ }^{12}$. Además del cuy, en esa obra puede verse maíz, ají y algunas frutas sobre la mesa.

La pintura también constituye un modo de marcar distinciones y separar a los cristianos de los réprobos o de los enemigos de la fe. Para el primer caso están las representaciones del infierno. Ellas incluyen personajes muy variados, que provienen de todas las etnias y estamentos de la sociedad. En esas imágenes no faltan dignatarios eclesiásticos, nobles españoles y caciques indios, lo que muestra que en la otra vida las distinciones y privilegios terrenales ya no desempeñan papel alguno. Es más, en el mural pintado por Luis de Riaño (n. Lima, 1596) en Andahuaylillas para representar el camino hacia el infierno, los caminantes que transitan por él son personajes de aspecto europeo, ataviados con elegancia.

${ }^{12}$ Una pintura análoga (1748), obra de Marcos Zapata, se encuentra en la Catedral del Cusco. En "La Sagrada Familia en Nazareth" (1665), el pintor indio Diego Quispe Tito muestra a María mientras hila a la manera andina. 


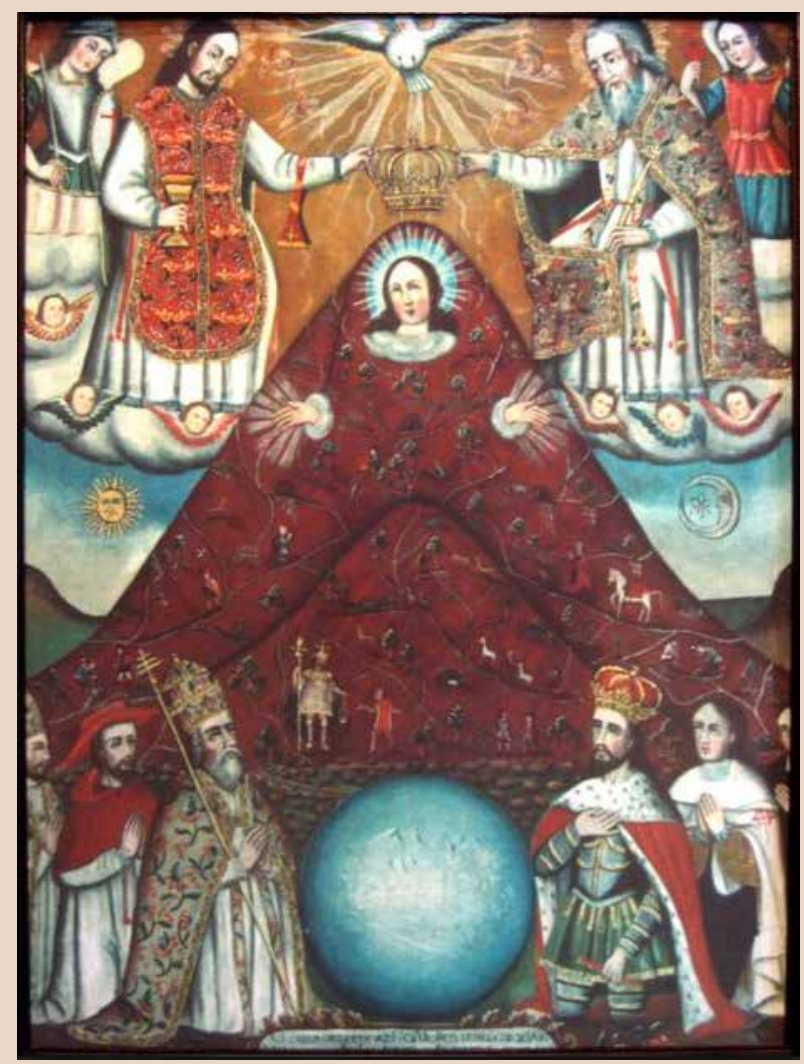

Figura 5. Virgen de Potosí.

Para el segundo caso están las imágenes de los musulmanes, que aparecen de modo constante en las iglesias cristianas, normalmente caídos en el suelo, debajo de la figura del Apóstol Santiago, llamado "Matamoros" (Fig. 6). En esas pinturas, el Santo, montado en su caballo, combate con su espada a los enemigos de la Iglesia. El caso más notable es, quizá, un cuadro que se halla en la iglesia de la Compañía en el Cusco, llamado "El triunfo de san Ignacio sobre los herejes". Allí, el fundador de los jesuitas aparece derrotando a un grupo de musulmanes, que están tumbados en el suelo; pero, para sorpresa nuestra, esas figuras corresponden a diversos reformadores (Wiclef, Hus, Melanchton, Lutero, Calvino y Ecolampadio), según se indica en las inscripciones que llevan sus respectivos turbantes. Es decir, nos encontramos aquí con una representación doble de los enemi- 
gos de la Iglesia en ese tiempo: musulmanes y protestantes. Se trata de un ejercicio muy notable, porque ninguno de los indios que vería ese cuadro iba a tener la más mínima posibilidad de encontrarse en su vida con un cristiano reformado y, mucho menos, con un musulmán. Pero ese tipo de representaciones contribuyeron a reforzar la propia identidad y establecer un enemigo común a los españoles y a los indios convertidos a la fe cristiana, un enemigo que, por estar muy lejos, no representaba un peligro de división de la propia sociedad.

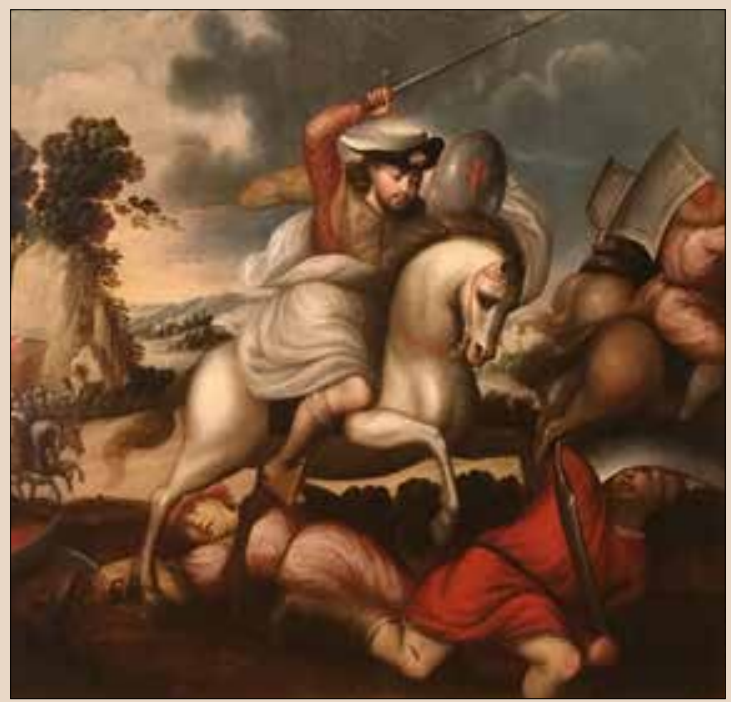

Figura 6. Matamoros.

Tenemos, entonces, que por todas estas vías la pintura presentó y propuso la imagen de una sociedad que está llamada a un destino trascendente, pero que experimenta obstáculos en ese camino. Estas dificultades muy variadas, comenzando por la propia pecaminosidad que afecta a todos los hombres. Otros impedimentos atacan directamente el fundamento espiritual de la comunidad, como es el caso de los herejes y los lejanos musulmanes, que niegan la necesidad de una Iglesia visible y combaten los sacramentos. Pero la fe cristiana de los creyentes no está indefensa. De una parte, la Iglesia cuenta con doctores capaces de combatir la herejía con su ciencia. Son famosas las imágenes de Santo Tomás de Aquino defendiendo 
la Eucaristía de los ataques de los musulmanes, como se ve en una pintura que está en la iglesia de San Pedro de Lima. Pero como las ideas no bastan para luchar contra el mal, también estaba la figura del rey de España que, espada en mano, acompaña al Aquinate y lo ayuda a defender la custodia eucarística de unos moros que intentan derribarla. En la mentalidad de la época, América no estaba ausente de la lucha contra la herejía, porque prestaba una valiosa contribución cuando enviaba a España la plata y otros metales que permitían financiar esas empresas guerreras acometidas en defensa de la fe.

También influyó la pintura a la hora de establecer una determinada mirada histórica o una peculiar visión de los hechos que permitiera reconciliar visiones y versiones contrapuestas. Fueron frecuentes las pinturas sobre los reyes del Perú, como la que se encuentra en la Catedral de Lima, que comienza con los monarcas incas y sigue con los retratos de Carlos V, Felipe II, etc., como un modo de destacar la continuidad en el ejercicio del poder. Así se presentó la llegada de los españoles simplemente como un cambio de dinastía, similar al que tuvo lugar en España con el reemplazo de los Habsburgo por los Borbones. El recurso a la figura de la traslatio imperii fue acompañado, en un principio, del empeño de la corona por conseguir una detallada información sobre las creencias y costumbres de las antiguas civilizaciones, una tarea que debían llevar a cabo tanto las autoridades civiles como los propios misioneros, para recopilar un material que permitiera escribir una historia oficial de las Indias. Con todo, se trata de un empeño no exento de contradicciones, si se tiene en cuenta que en 1558 Felipe II prohibió la publicación de libros sobre las antiguas civilizaciones americanas, lo que afectó nada menos que a la monumental obra que al respecto estaba escribiendo Bernardino de Sahagún, que nunca pudo ver publicado en vida su notable trabajo (Pérez Amador Adam, 2011, pp. 25-26). Se observa aquí una tensión entre la convicción de que la memoria de las antiguas culturas debe ser preservada y el deseo de que esa conservación se ajuste a los intereses del poder. En todo caso, los efectos de esas limitaciones no fueron absolutos, porque a comienzos del siglo siguiente el Inca Garcilaso escribió y publicó la primera parte de sus Comentarios reales (1609), dedicada a la historia de los incas, sus antepasados.

Una importancia análoga al cuadro de los reyes del Perú tiene una de las más famosas pinturas de la época virreinal, que también se encuentra en la iglesia de la Compañía, en el Cusco. Ella muestra la boda de un noble español, Don Martín García Oñez de Loyola (Vizcaya 1553-Chile 1598) con la Nusta (princesa) Doña Beatriz Clara Coya (¿? 1536-Lima 1600). Don Mar- 
tín era sobrino de San Ignacio de Loyola y había capturado nada menos que al inca rebelde Túpac Amaru I, tío de la esposa que figura en la pintura. En la misma imagen se muestra un acontecimiento que tuvo lugar años después, la boda de la hija de ambos con un hijo de San Francisco de Borja, un acontecimiento que enlazó las familias de dos emblemáticas figuras de la Compañía. Muchas veces se ha señalado el contraste entre la escena de la boda mestiza representada por este cuadro y la realidad de las incursiones del hombre blanco en otros lugares del mundo, sea en Sudáfrica, en la India, Norteamérica inglesa o en China, donde difícilmente habría sido pensable una unión solemne como esta. Aquí, la excepcionalidad del acontecimiento, reflejado en el hecho de que haya sido recogido en esa pintura, no está dada por el carácter interracial de la boda, ya que estas uniones fueron muy frecuentes, sino por el linaje de los contrayentes. Ahora bien, aunque todo en este cuadro está en orden, y no parece reflejar tensión alguna, el mestizaje que se inició con esa unión y otras semejantes fue una empresa cultural de gran envergadura, que abarcó el derecho, el arte, la política, el urbanismo, la comida, la liturgia y la guerra. Ciertamente, no estuvo exenta de problemas, pero marcó hasta hoy el modo de ser hispanoamericano.

\section{EL TEATRO Y LA MÚSICA}

La mayor novedad que trajeron los españoles en el campo artístico fue, sin duda, el teatro. Los antecedentes precolombinos de esta expresión artística, como el Rabinal Achí (Tedlock, 2003), son escasos y no parecen haber tenido la amplia presencia social que después tuvieron los autos sacramentales y demás manifestaciones dramáticas que aparecían constantemente en el Cusco, Lima o el Virreinato de Nueva España. Tal como en la España barroca, la misma vida religiosa adquirió un carácter teatral. En esta línea, los indios desarrollaron un gran gusto por las procesiones, como puede verse en la famosa serie del Corpus cusqueño, que muestra la participación de los diversos grupos sociales en esa ceremonia religiosa. Esta afición de carácter religioso y teatral se mantiene hasta el día de hoy (Gisbert, 2007, p. 60). Conviene tener presente que, aunque los indios en su mayoría no solían recibir la Eucaristía (Martínez Ferrer, 2017, pp. 214-217 II, cap. XX), sí desarrollaron libremente la posibilidad de contemplarla, particularmente en esas procesiones, y de expresar su veneración cubriendo de flores los caminos por donde iba a pasar el sacerdote que la portaba, y uniéndose a los cantos en su honor. 
No solo las fiestas del culto, sino también acontecimientos seculares, como la llegada de un virrey o la entronización de un nuevo monarca en España, iban acompañadas de carros alegóricos y representaciones populares, que muchas veces se traducían en un arte efímero, tan del gusto de los hombres del Barroco: unos fuegos artificiales, una danza que pasa en unos minutos, o una construcción de cartón y pintura que termina siendo presa de las llamas y desaparece en un instante en medio del regocijo popular. En este tipo de manifestaciones apenas hay lugar para el desencuentro entre las culturas. Ellas forman un espacio común donde todos se reúnen, tienen su lugar propio y cada grupo resulta importante para que la celebración se lleve a cabo. De este modo, por su carácter compartido, la fiesta se transforma en un elemento de integración (Cruz de Amenábar, 1997).

Por su parte, la música es una de las artes que, por su índole inmaterial, admite mayor complejidad y está abierta a múltiples influjos. Es, además, la más inmaterial de todas. Los europeos trajeron a América nuevos instrumentos y un elaborado sistema de escritura musical, que permite reproducir una pieza sin haberla oído nunca antes a su creador. Esto les abrió la posibilidad de recibir influencias de lugares muy distintos, y aprovechar las experiencias de los compositores precedentes. En el Nuevo Mundo, la música estuvo al servicio de la liturgia y produjo una especial fascinación en los indios. Por otra parte, la flexibilidad del Barroco permitió recoger e integrar en nuevas creaciones toda la experiencia de un mundo desconocido para los europeos. Entre los elementos que se incorporaron están, naturalmente, las lenguas autóctonas. Son muchas las piezas donde en la música hay una fusión entre lo europeo y lo americano, pero la letra está escrita en quechua o alguna otra lengua propia del Nuevo Mundo, como se escucha hasta hoy en "Apu Yaya Jesucristo" u otras canciones que se interpretan en las ceremonias populares de carácter religioso en el Perú u otros países. Especial valor tiene la labor de los compositores jesuitas en las misiones guaraníes, cuya riqueza aún hoy se sigue descubriendo ${ }^{13}$.

${ }^{13}$ Conocida es la historia de Domenico Zipoli (1688-1726), uno de los compositores más famosos de su época en Roma, que se trasladó a Córdoba, capital de la provincia jesuítica del Paraguay, para componer allí innumerables obras destinadas a las misiones. También en la literatura se realiza un esfuerzo de conexión entre las culturas, aunque no es objeto de este trabajo. Un intento notable en esa dirección es el de Carlos Sigüenza y Góngora, quien, ante la dificultad de hacer compatible el catolicismo con las religiones precolombinas, decide identificar lo más noble del pasado religioso azteca, el dios Quetzalcóatl, nada menos que con el apóstol Tomás, que, según su barroca reconstrucción, habría predicado en el Nuevo Mundo antes de la llegada de los españoles (López Farjeat y Zagal Arreguín, 1998, p. 74; Paz, 1983, pp. 55-56). 


\section{CONCLUSIÓN: DE LAS ARMAS AL ARTE}

El encuentro entre Europa y América requirió la fuerza de las armas para llevarse a cabo, pero no fue obra de la pura violencia. Desde el principio cabe advertir intentos más o menos eficaces por establecer puntos de contacto entre las culturas. Uno de ellos fue el arte, que en América se desplegó de manera muy original en sus distintas manifestaciones: arquitectura, pintura, música y artes escénicas. Además, en el caso del arte, la dependencia de las mediaciones lingüísticas fue mucho menor que cuando se trataba del derecho. Por otra parte, los indígenas fueron protagonistas muy relevantes del proceso de creación artística, lo que facilitó que el arte se constituyera en un espacio de encuentro mucho menos conflictivo que los otros ( $y$ en ese sentido los supera), en el que además se incorporaron muchos elementos del pasado prehispánico, lo que facilitó el que los indios pudieran reconocerse en él.

El nuevo arte que surgió en América tuvo, además, otra virtud: la de comunicar a pueblos que hasta la llegada de los españoles se hallaban desvinculados. Ciertamente el arte de Nueva España tenía importantes diferencias con el que se hacía en Quito o el Cuzco, pero existió un indiscutible aire de familia, que permitió que, por encima de sus diferencias étnicas y lingüísticas, todos esos pueblos, hasta entonces desconectados, participaran de una experiencia común.

\section{REFERENCIAS}

Arriaga, P. J. de. (1999). La extirpación de la idolatría en el Pirú (H. Urbano, Ed.). Cusco: Centro de Estudios Regionales Andinos "Bartolomé de Las Casas".

Cabello Pérez, F. (1989). La portada retablo en el siglo XVIII en Hispanoamérica. Mayurqa: revista del Departament de Ciències Històriques i Teoria de les Arts, 22(2), 70-718.

Cruz de Amenábar, I. C. de. (1997). Arte festivo barroco: un legado duradero. Laboratorio de Arte: Revista del Departamento de Historia del Arte, 10, 211232.

De Mesa, J. y Gisbert, T. (1982). Historia de la pintura cuzqueña (2a ed.). Lima: Fundación AN Wiese: Banco Wiese.

Domínguez Reboiras, Fernando. (2011). La Inquisición española y los indios. En W. Oesterreicher y R. Schmidt-Riese (Eds.), Esplendores y miserias de la evangelización de América: Antecedentes europeos y alteridad indígena (pp. 45-71). Berlin-New York: Walter de Gruyter. 
Estenssoro, J. C. (2003). Del paganismo a la santidad: la incorporación de los indios del Perú al catolicismo, 1532-1750. (G. Ramos, Trad.) (1 ${ }^{\mathrm{a}}$ ed.). Lima: IFEA, Instituto Francés de Estudios Andinos: Pontificia Universidad Católica del Perú, Instituto Riva-Agüero.

Gisbert, T. (1994). Iconografía y mitos indígenas en el arte (2a ed.). La Paz: Fundación BHN-Gisbert.

(2007). El control de lo imaginario: La teatralización de la fiesta. En La fiesta en el tiempo (pp. 47-64). La Paz: Unión Latina.

Gisbert, T. y De Mesa, J. (1974). La exteriorización del culto. Capillas abiertas y atrios en el Perú. Anuario de Estudios Americanos, 31, 973-1003.

Gutiérrez, R. (1995). Transculturación en el arte americano. En R. Gutiérrez (Ed.), Pintura, escultura y artes útiles en Iberoamérica, 1500-1825. Madrid: Cátedra.

López Farjeat, L. X., y Zagal Arreguín, H. (1998). Dos aproximaciones estéticas a la identidad nacional: una filosofía de la cultura desde el barrocco y el surrealismo ( $1^{\text {a }}$ ed.). Monterrey: Universidad Autónoma de Nuevo León.

Martínez Ferrer, L. (2017). Tercer Concilio Limense (1583-1591). Edición Bilingüe de los decretos (J. L. Gutiérrez, Trad.). Lima: Pontificia Università della Santa Croce-San Pablo-Facultad de Teología de Lima.

Mujica Pinilla, R. (2016). La imagen transgredida: ensayos de iconografía peruana y sus políticas de representación simbólica ( $1^{\mathrm{a}}$ ed.). Lima: Fondo Editorial del Congreso de Perú.

Paz, O. (1974). "Sor Juana Inés de la Cruz". En Las peras del olmo (pp. 34-48). Barcelona: Seix Barral. . (1983). Sor Juana Inés de la Cruz o Las trampas de la fe ( $3^{\mathrm{a}}$ ed.). México: Fondo de Cultura Económica.

Pérez Amador Adam, A. (2011). De legitimatione imperii Indiae Occidentalis: la vindicación de la Empresa Americana en el discurso jurídico y teológico de las letras de los Siglos del Oro en España y los virreinatos americanos. MadridFrankfurt am Main: Iberoamericana; Vervuert.

Tedlock, D. (2003). Rabinal Achi a Mayan drama of war and sacrifice. Oxford; New York: Oxford University Press.

Terán Bonilla, J. A. (1992). Manifestaciones barrocas en la arquitectura religiosa producida por el pueblo región Puebla-Tlaxcala ( $1^{\mathrm{a}}$ ed.). México: Gobierno del Estado de Puebla, Secretaría de Cultura Comisión Puebla V Centenario. . (2017). Arquitectura barroca popular en la región Puebla-Tlaxcala. Expresión del mestizaje. En Campos Vera, N. (Ed.), Barroco. Mestizajes en diálogo. VIII Encuentro internacional sobre Barroco (pp. 49-58). La Paz: Fundación Visión Cultural-Universidad Nuestra Señora de La Paz.

Valenzuela, F. A. (2013). La debilidad institucional del gremio de pintores de Cusco en el período colonial: un estudio historiográfico. CLAHR: Colonial Latin American Historical Review, 1(4), 381-402. 